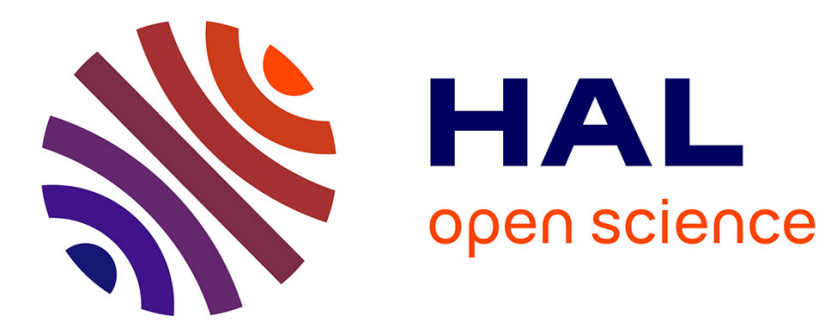

\title{
The Characterization and Definition of Public Performance: An Application to Local Government Authorities
}

Christophe Maurel, David Carassus, Christophe Favoreu, Damien Gardey

\section{- To cite this version:}

Christophe Maurel, David Carassus, Christophe Favoreu, Damien Gardey. The Characterization and Definition of Public Performance: An Application to Local Government Authorities. Gestion et management public [2012-..], 2014, 2 (3), pp.23-44. hal-02431157

\section{HAL Id: hal-02431157 \\ https: / hal-univ-pau.archives-ouvertes.fr/hal-02431157}

Submitted on 9 Dec 2020

HAL is a multi-disciplinary open access archive for the deposit and dissemination of scientific research documents, whether they are published or not. The documents may come from teaching and research institutions in France or abroad, or from public or private research centers.
L'archive ouverte pluridisciplinaire HAL, est destinée au dépôt et à la diffusion de documents scientifiques de niveau recherche, publiés ou non, émanant des établissements d'enseignement et de recherche français ou étrangers, des laboratoires publics ou privés. 


\title{
The Characterization and Definition of Public Performance:
}

\author{
An Application to Local Government Authorities
}

\author{
CARASSUS David, FAVOREU Christophe, GARDEY Damien, MAUREL Christophe,
}

Over the last few years, the theme of public performance (PP) has been increasingly invoked in political, administrative and academic circles. Particularly for local authorities, the use of performance approaches is on the rise, contributing to the management of local government initiatives and structures (Folz and al., 2009; Fryer and al., 2009; Newcomer, 2007; Wechlsler and Clary, 2000). The concept of public performance, however, is not precisely defined, nor does it cover a set of common practices based on an explicit, recognized framework. It has a multiplicity of overlapping definitions that are often inadequate, either because they are too general or because they have been uncritically adopted from other disciplines. Moreover, the notion is also a vague one, since it means different things to different actors. A number of studies reinforce this analysis, pointing out that public practices suffer from a lack of abstraction or from oversimplification, due to an uncritical transfer of practices and tools from the private sector (Halachmi and Bouckaert, 1996; Moynihan, 2005).

It is thus essential, in a professional and academic context that demands it, that technical and instrumental developments be preceded by a process of abstraction that enables an analysis of the concept of public performance. Indeed, the models of the representation and measurement of public performance have gained in richness by broadening the concept of performance, but the hypotheses underlying the models-especially the multidimensionality of public performance-have never been never tested.

To meet this need, we have developed both a holistic characterization and a definition of the public performance. On the basis of the literature on public performance values, performance management models, and the definition of organizational performance, we derive the specific characteristics of public performance. We then test the hypotheses underlying the model, applying a quantitative methodology to the results of a questionnaire-based survey conducted with 350 French local authorities. Finally, using statistical analysis, we put forward a definition of public performance.

\section{A framework for studying the characteristics of local public performance}

We first present and analyze the characteristics and dimensions of the main public performance management models found internationally ( $\$ 1.1$ ) based on a synthesis produced by Guenoun (2009) and then, given the partial nature of these models, we develop a more complete public performance model (§1.2).

\subsection{Public performance management models}

Over the last two decades or so in the developed countries, performance management systems (PMS) have developed greatly, thanks to a transfer of know-how from the private to the public sector. These systemsare based on New Public Management (NPM), which aims to make public and governmental organisations more businesslike (Jansen, 2008).The first performance management approaches were based on classical economic theory (public choice theory), with a focus on the transformation of inputs into outputs. They then became more complex, first by integrating the notion of results (the introduction of outcomes and relevance, a current of NPM; Bouckaert, Talbot) and then that of stakeholders (the EIPA and Moullin models). 
We group the models of public performance management into two groups: those that adopt a largely economic approach (\$1.1.1), and those with a more focused stakeholder orientation (modelswhere citizens participate directly in the process of assessing and measuring the performance of government - §1.1.2).

\subsubsection{Performance management models with a strongly economic orientation}

Analysis of the literature reveals 3 models underpinned by an economic approach to performance: the model of Public Choice theory, model of NPM (Hood, 1991, 1995) and the model of Bouckaert and Pollitt (2004).

The public choice theory has adapted for the public sector the classic Inputs-Outputs model by distinguishing between the outputs (products, deliverables) and the outcomes (impacts, effects), each derived from a distinct production function. The Inputs-Outputs-Outcomes (IOO)model provides a wider range of criteria for the evaluation of organizational performance. Indeed, outcomes are measured by non-financial indicators that represent the social benefits deriving from the action, whereas outputs designate activities that will not necessarily lead to outcome-type results. This model integrates the three elements of the $3 \mathrm{E}$ model: economy is integrated into the inputs, efficiency is the ratio of outputs to inputs, and outcomes includeeffectiveness. According to Boyne (2002), this model makes explicit the performance dimensions that are, at best, implicit in the $3 \mathrm{E}$ model.This approach is complemented by Talbot (1999), who addresses thequestion of evaluation by proposing a public performance model evaluated in terms of efficiency, effectiveness, economy, and relevance of results. This model introduces certain notions derived fromTotal Quality Management (TQM).

Another approach is proposed by the NPM current. Here, less attention is paid to compliance with formally prescribed processes and rules. NPM tries to combine an internal perspective with a customer perspective, thus focussing on both internal processes and outputs. Hood (1995), by positioning his work within the theoretical framework of New Public Management, highlights five principles that enable one to grasp the notion of performance:

- Management by results, which fundamentally modifies the role of the public servant, changing it from administrator to manager responsible for results;

- A measure of the impact of actions, which supposes the prior definition of the finalities and strategic objectives of the local authority, the taking into account of the contribution of its partners, and the improvement of the circulation of information between partners;

- The pursuit of client satisfaction, the action of the Administration being totally focused on user satisfaction. This principle supposes the deployment of tools for analyzing needs and expectations and the development of differentiated services;

- A determination to set public finances on a sound footing, which entails cost analysis and, for certain reforms, the outsourcing or privatization of certain services;

- An improvement in the accuracy and transparency of public accounts. This principle, adopted from the competitive sector, aims to apply the principles of private accounting to the public sector and, especially, to take account of the local authority's assets. It supposes the presentation of a balance sheet that reconstitutes, in particular, the value of the local authority's fixed assets. It is accompanied by the certification of the accounts by an external auditor.

Thus, according to Hood, NPM is about accountability in connection with results, and it is thought to eliminate some of the differences between private and public organizations.

The articulation of the different systems of public performance management is modeled by Bouckaert and Pollitt (2004) in the following way. On one hand, the management system focuses on 
both the internal dimension of performance and the external one (which takes account of socioeconomic problems, interprets them in terms of needs, and then evaluates the external outcomes of public action); on the other hand, it uses a performance management loop that links the internal and external dimensions of performance together. Finally, it breaks internal and external performance down into several performance objects: relevance of objectives to needs, efficiency of the production process in terms of resource utilization, effectiveness of management in terms of final or intermediate outcomes compared to objectives, and overall utility of public action in terms of final outcomes compared to needs identified.

In addition to public performance management models that adopt an economic approach, the literature also deals with models that use a stakeholder approach.

\subsection{2. "Partnership" models of public performance management}

Another approach to public performance models consists in integrating the participation of citizens into the representation and measurement of performance. This idea is based on the TQM current, where customers are involved in the definition of outputs and outcomes, and on the democratic participation/governance current, in which citizens are invited to participate in the life of public organizations (stewardship), (Armstrong, 1997; Hirst, 2000; Vigoda, 2002). The quality approach gave rise to a European model (EIPA, 2006), while the other(specify which other) approach adapts Kaplan and Norton's (1996) Balanced Scorecard.

We will now present two models based on a stakeholder approach to public performance management: the Common Assessment Framework (CAF) (EIPA, 2006) and the Public Sector Scorecard (PSS) (Moullin, 2002). Following a European initiative in 1998 to develop a tool to support the improvement in quality of public management, a group of experts presented a Common Assessment Framework (CAF) in 2000 in Lisbon. Drawing on the ideas of the Excellence model developed by the European Foundation for Quality Management (EFQM), a new version was developed in 2006, paying greater attention to the specificity of the public sector (for example, the primacy of law; ethical behaviour based on common principles) and emphasizing modernization, innovation and the holistic character of the model. The CAF distinguishes four types of results of public initiatives, two of which are relative to outcomes (EIPA, 2006):

- the "beneficiary" results concerning the customers or the targets directly addressed by the public organization's services; measured externally by the satisfaction of direct customers and internally by the number of complaints or the extent to which commitments made in the service charter were met;

- the "social" results concerning the direct and indirect environment of the organization, measured by the impact on society and on the environment.

In this Excellence model derived from the TQM current, one finds, adapted to the public sector, notions of performance used in the private sector, especially the issue of stakeholder access to information (De Brujin 2002).Similarly, by seeking to integrate different dimensions of performance, the distinctive traits of the Balanced Scorecard (BSC) make it compatible with the representation of the performance of a private or public sector organization.

The stress laid on the linking of financial and non-financial indicators is highly compatible with the principle that public organizations are not primarily profit-seeking. Moreover, the BSC's objective to align indicators with the interests of stakeholders (customers, shareholders, employees) corresponds well to the multiple beneficiaries of public initiatives (Fryer and al., 2009; MC Adam and al., 2007). The BSC could thus be seen as a minimal concession by public organizations to the injunction to measure their performance (Chow et al., 1998). Indeed, studies of practices confirm its high rate of penetration in the public sector (Aidemark, 2001; Ax andBjornenak, 2000; McKendrick and Hastings, 2002). In accordance with this trend, Moullin (2002) has developed a Public Sector Scorecard (PSS) 
intended to "provide an overall framework for performance measurement and service improvement, adapting the BSC to the culture and values of the public and semi-public sectors". The model was adapted by adding a new dimension of performance: the "user/stakeholder" perspective, involving the measurement of user satisfaction and user perception of the service. The PSS thus consists in five perspectives. The key element in the model is the integration of users and stakeholders in the objectives-setting process. The aim is to align strategy, process and performance measurement with the needs and expectations of direct users and other stakeholders. Whereas the traditional BSC only aims to assure consistency between the different performance perspectives, the PSS seeks to go beyond the borders of the organization by including representatives of partner organizations and other reference groups in the PSS management committee (Moullin, 2002). The strategy map developed within the framework of the PSS is also notably different from the generic BSC in that the participants are invited to reflect on the desired effects of initiatives and to identify the main risk factors (Neely et al., 2002). This modified BSC has been adopted by certain entities of the UK's National Health Service, by a British local government, and by the South African Ministry of Transportation (Moullin, 2002). It highlights the relationship between the strategy map and the progress achieved relative to the predetermined objectives. This extension of the BSC to include five perspectives and the idea of using it as a platform to support relations between stakeholders recurs in most of the adaptations of the BSC to the public sector. Thus Chapet (2007) distinguishes the five perspectives (goals, realizations, processes, contributions, competences) and identifies a stakeholder for each of them. This perspective/stakeholder linking is designed to promote the alignment of perspectives with the expectations of stakeholders.

Having presented the main models of public performance management, we will now present an analysis that prepares the ground for a more holistic model.

\subsection{A holistic performance management model}

In a systemic approach to management, performance management should prove useful at the three levels of systems regulation traditionally analyzed in the literature:

- At the first level of regulation: a public organization pursuing with greater effectiveness and efficiency the objectives set by the political authorities;

- At the second level of regulation: questioning the relevance of the objectives pursued and their appropriateness in light ofchanges in the environment and in citizens' needs; through this process, greater transparency and a better dialogue between stakeholders are facilitated;

- At the third level of regulation: learning or deutero-learning (Argyris andSchön, 1978), enabling the political and administrative managers to better understand the consequences of their choices and to assume greater responsibility in the conduct of public policy.

Taking into account these three levels favors the development of a holistic conception of public performance.We base our analysis of the characteristics and dimensions of public performance on a comparative study of the models presented. We first center our argument on the specific dimensions of public performance and then we highlight the characteristics associated.

\subsubsection{An analysis of the dimensions of performance}

There are three dimensions of public performance, in relation with the inputs, outputs and outcomes of the public service offer, as revealed by the precedent model.

The first dimension, in relation the inputs of the public organization, corresponds to the means mobilized by the organization. 
With the organizational means, we associate the organizational dimension of public performance, characterized by the appropriate adaptation of human, financial and technical resources (Bouckaert and Pollitt's model, 2004), in addition to the culture and structure of the organization, to the public service offer (the CAF, 2006).

With the human means, we associate the human dimension of public performance, characterized by the commitment, motivation and mobilization of the personnel around the strategy (CAF model), and by the response to the personnel's aspirations to well-being and development (CAF model, PSS model). With the financial means, we associate the financial dimension of public performance, characterized by the control of spending defined and deployed appropriately and economically and made in compliance with all relevant policies, and by the optimization of revenue and the respect of regulations (Talbot, 1999; Hood's model). The second dimension, in relation to the outputs of the public organization, is characterized by the adaptation of the quantity and quality of the local public service offer to the needs of users (IOO model; PSS model). We named this specific dimension, the public service dimension. The third dimension, in relation with the outcomes of the public organization, is characterized mainly by the pursuit of the general interest, social justice, and the regulation of economic activity (Bouckaert and Pollitt's model, 2004) via (1) a public service offer that meets citizens' and the local environment's needs and degrees of satisfaction (Hood's model, 1995), and (2) reliable, open communication with stakeholders on initiatives undertaken and resources deployed (CAF model). We named this specific dimension, the territorial dimension. It seems this dimension is specific to the local authorities or local administration/agencies.

A comparative analysis of the management models studied allows us to highlight five dimensions of public performance: three dimensions applicable to all types of organizations (the organizational, human and financial dimensions), and two dimensions relevant to the public sector only (the territorial and public service dimensions).

\subsubsection{An analysis of the characteristics of public performance}

The first three dimensions pertaining to the capabilities of the organization in turn suggest five characteristics of public performance (PP).

Public performance, in its organizational, human and financial dimensions, can have different objects of analysis (1). Public Choice evokes two objects of analysis: administration (particularly financial resources) and individuals. As for the NPM current, it proposes departments/individuals. These objects are associated with objectives (2) and measures (3) used in the PMS. 'Objectives' correspond to the control of public spending and the optimization of revenue (Hood's model; the PSS model) assessed by economy, efficiency and effectiveness.

Moreover, these models show different rationales (4) associated with the use of resources in term of compliance, legality and productivity (Talbot; Hood's model; Bouckaert and Pollitt's model; PSS). The PP data can be used for different actors; the targets (5) are the administration and employees for their use of resources, and the government, banks and taxpayers for their allocation of resources (Hood's model; PSS model; the CAF).

Related to the public service dimension (at the level of outputs), the objects of PP are the public service initiatives undertaken by the organization (Talbot; PSS model). The rationales associated with the realization of these initiatives concern effectiveness and efficiency ((Talbot's model; Hood's model; PSS model). The associated objectives and measures correspond to the production of public services of sufficient quantity and quality, satisfying the user (Hood's model; PSS model; "CAF"). The targets of the public service offer are the users ((IOO model; "CAF").

Related to the territorial dimension of PP, the objects are the public policies implemented (Talbot's model; PSS model). The rationales associated with the execution of these policies concern the regulation of economic activity, the general interest and social justice (Bouckaert and Pollitt's model). 
The associated objectives and measures correspond to a public service offer that meets the needs of the public organization's stakeholders and generates lasting effects on its territory ((Hood's model; Bouckaert and Pollitt'smodel; "CAF"). The targets of the impact of public policies are citizens and companies ((Hood's model; PSS model;Moreover, PP includes the characteristic "learning" (6), at the political and administrative level, derived from the practice of management control and strategic control. Administrative learning corresponds to the rational adaptation of resources to the objectives of the public service offer (Bouckaert and Pollitt's model; Talbot). Political learning concerns the reorientation of political objectives themselves in light of their environmental impact and/or the relevance of their resources deployed (Bouckaert and Pollitt's model; Talbot; the PSS). Finally, political learning can take the form of the adaptation of the means to the expected effects of public policy (Bouckaert and Pollitt's model; "CAF model").Overall, the comparative analysis of the PPM models reveals six specific characteristics: objects, objectives, measurements, rationales, targets and learning. We can summarize the preceding analyses in a synoptic table, showing the partial character of the public performance models. Indeed, none on them integrates the entire set of specific characteristics and dimensions.

Table 1: Synoptic table of the characteristics and dimensionsof public performance management models

\begin{tabular}{|c|c|c|c|}
\hline \multicolumn{2}{|c|}{ PPMmodels } & Characteristics of PP & $\begin{array}{l}\text { Evaluation dimensions } \\
\text { of PP }\end{array}$ \\
\hline \multirow{4}{*}{$\begin{array}{c}\text { Economic- } \\
\text { orientedapproach }\end{array}$} & $\begin{array}{l}\text { IOO (public } \\
\text { choicetheory) }\end{array}$ & $\begin{array}{c}\text { Object } \\
\text { Objective } \\
\text { Measurement } \\
\text { Rationale }\end{array}$ & Financial resources \\
\hline & HOOD (1995) & $\begin{array}{c}\text { Object } \\
\text { Objective } \\
\text { Measurement } \\
\text { Learning } \\
\text { Target } \\
\text { Rationale }\end{array}$ & $\begin{array}{l}\text { - Territorial dimension } \\
\text {-Organizational and } \\
\text { financialresources }\end{array}$ \\
\hline & TALBOT (1999) & $\begin{array}{c}\text { Object } \\
\text { Objective } \\
\text { Measurement } \\
\text { Target }\end{array}$ & Organizationalresources \\
\hline & $\begin{array}{l}\text { BOUCKAERT \& } \\
\text { POLLITT (2004) }\end{array}$ & $\begin{array}{c}\text { Object } \\
\text { Objective } \\
\text { Measurement } \\
\text { Learning } \\
\text { Rationale } \\
\end{array}$ & $\begin{array}{c}\text { - Territorial dimension } \\
\text { - } \\
\text { Organizationalresources }\end{array}$ \\
\hline \multirow{2}{*}{$\begin{array}{c}\text { Stakeholder- } \\
\text { orientedapproach }\end{array}$} & CAF (EIPA, 2006) & $\begin{array}{l}\text { Measurement } \\
\text { Learning } \\
\text { Target }\end{array}$ & $\begin{array}{l}\text { - Territorial dimension } \\
\text { - Public services } \\
\text { - Organizational, human } \\
\text { and financial resources }\end{array}$ \\
\hline & $\begin{array}{l}\text { PSS (MOULLIN, } \\
\text { 2006) }\end{array}$ & $\begin{array}{c}\text { Objective } \\
\text { Measurement } \\
\text { Learning } \\
\text { Target } \\
\text { Rationale } \\
\end{array}$ & $\begin{array}{l}\text { - Territorial dimension } \\
\text {-Organizational and } \\
\text { financialresources }\end{array}$ \\
\hline
\end{tabular}


We propose to go beyond the partial vision of these models by formulating a general proposition on the multidimensional character of public performance.

P1: Public performance is characterized byterritorial, publicservice, organizational, human and financial dimensions

To test this proposition, we formulate six sub-propositions that bring into relation the six characteristics of PP and their specific dimensions:

- P1.1:The objects of PP aremultidimensional

- $\quad$ P1.2:The objectivesof PP are multidimensional

- $\quad$ P1.3:Learning of PP is multidimensional

- $\quad$ P1.4:The measurementof PP is multidimensional

- $\quad$ P1.5:Thetargetsof PP are multidimensional

- $\quad$ P1.6:Therationalesof PP are multidimensional

On the basis of these propositions, we present the working model that will be tested in the local public context in the empirical section of the paper.

Figure 1: Working model of the characteristics of public performance

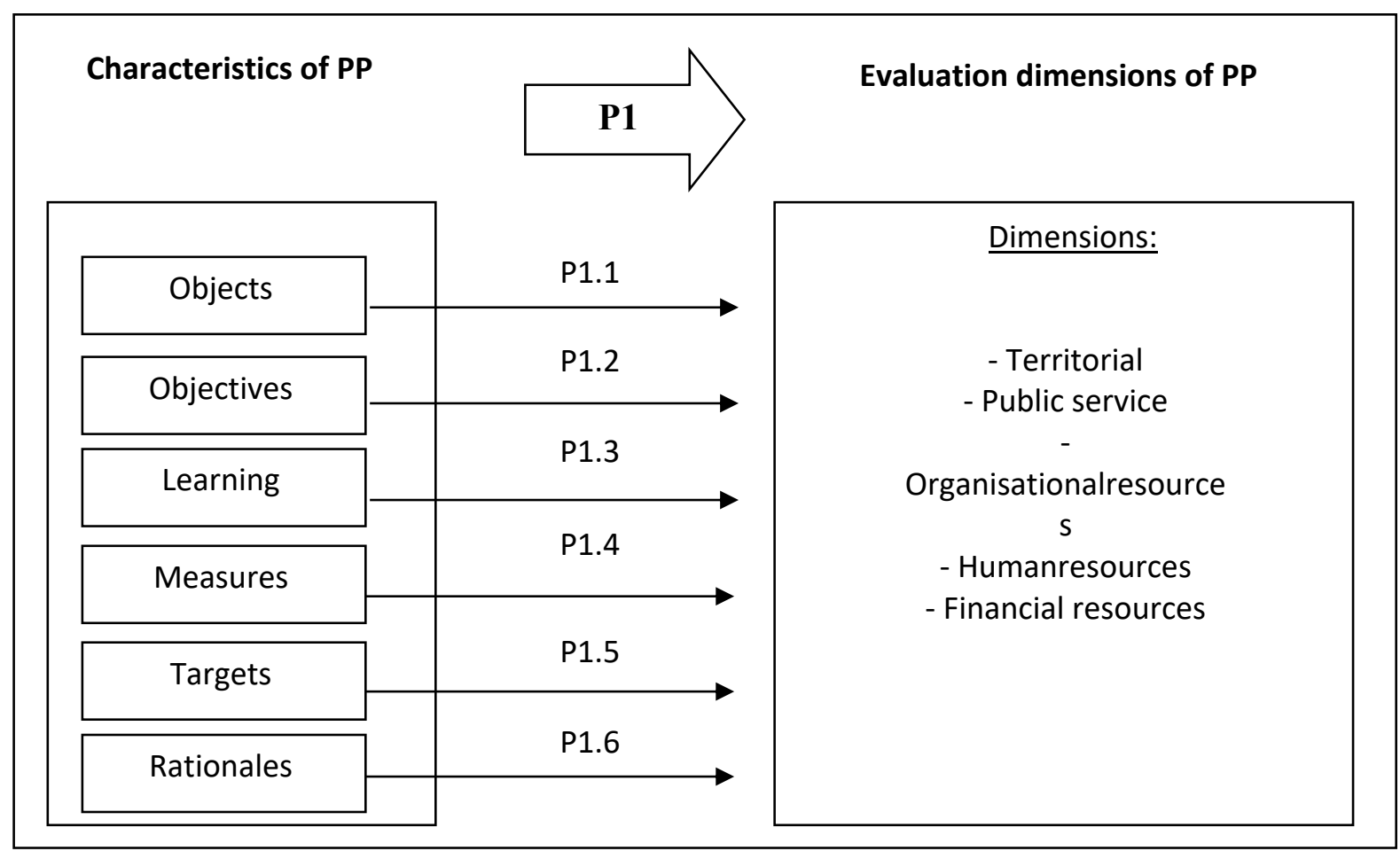

This model brings to light an explanatory variable concerning the characteristics of PP and an explained variable concerning the dimensions of PP. The relationship of these two variables to each other is the object of the six propositions on the multiple characteristics of PP, derived from proposition $\mathrm{P} 1$ of this study.

In order to test the empirical relevance of our working model, we will now use a quantitative methodology based on a survey conducted via a questionnaire. 


\section{Empirical analyses revealing the multidimensional character of local public performance}

The empirical analysis of our public performance characterization framework proceeds in several stages. We first present the methodology of the study, then the results of our analysis of the elements of the characterization framework.

\subsection{Methodology}

The approach adopted in our empirical study is that of hypothetico-deductive research. Indeed, on the basis of the public performance characteristics singled out, we put forward six hypotheses on the multiple character of each of the six components identified. To test these hypotheses, we sent a questionnaire to 350 French local government authorities, members of AFIGESE-CT (Association FInances-Gestion-Evaluation des CollectivitésTerritoriales), and received 147 useable replies of the highest-ranking officials.

Table 2: presentation of the respondents

\begin{tabular}{|c|c|}
\hline Number of response & 147 \\
\hline Repartition of positions & financial managers, 30\% \\
& management controllers, 29\% \\
& department heads, $29 \%$ \\
& general managers, 12\% \\
\hline $\begin{array}{c}\text { Repartition of population of the local } \\
\text { government authorities (mean: }\end{array}$ & $*^{*}<150,000: 75$ local authorities \\
$299,000)$ & $150<*<300,000: 26$ \\
& $300<*<500,000: 15$ \\
& $*^{*}>500,000: 32$ \\
\hline
\end{tabular}

The questionnaire was made up of an informational part and parts concerning the characteristics of PP (fig.1). Each characteristic includes variables from literature that were evaluated using a sevenpoint Likert scale on the degree of agreement (1: no agreement at all; 7: complete agreement).

We processed the data in two stages. First, using Cronbach's Alpha ${ }^{1}$ we checked the items of the six components of public performance. We then identified the most significant explanatory variables using regressions to check the presence of different dimensions derived from the literature review. As the variables to be explained were binary, we used logistic regressions ${ }^{2}$. The quality of these regressions was evaluated using the Nagelkerke coefficient and the percentage of correct rankings of

\footnotetext{
${ }^{1}$ Cronbach's alpha is used to determine if multiple items in a scale measure the same psychological dimension. Alpha is satisfactory to the scale from 0.6.

${ }^{2}$ Logistic regression is a multivariate model that is used when the dependent variable (Y) is qualitative, usually binary. The explanatory variables (independent variables $\mathrm{X}$ ) can be against by either qualitative or quantitative. The dependent variable is usually the occurrence or not of an event and the independent variables that may influence the occurrence of this event. The advantage of this technique is to quantify the strength of the association between each independent variable and the dependent variable, taking into account the effect of other variables in the model. The interpretation is easy because the coefficients estimated by the model are related mathematically with the odds ratio which represents the strength of the association between two factors.
} 
the individuals studied, and the regression coefficients were evaluated according to their degree of significance ${ }^{3}$.

In sum, each of the six characteristics of public performance identified (objects, objectives, measures, rationales, targets and learning) was presented and tested through their modalities derived from the analysis of the literature (cf. Part 1).

\subsection{Analysis of the objects of public performance}

To analyze the objects of PP, four variables were put forward to respondents: performance related to individuals, to the higher administration/departments, to the local authority in general, and to the initiatives undertaken (the public policies implemented).

Table 3: Result of the correlation on the variable "objects"

\begin{tabular}{|c|c|}
\hline Multi-object & $\alpha: 0.57$ \\
\hline Performance of individuals & $0.35^{* *}$ \\
\hline Performance of higher admin. & $0.55^{* *}$ \\
\hline Performance of local authority & $0.63 * *$ \\
\hline $\begin{array}{c}\text { Performance of public policies and of initiatives } \\
\text { undertaken }\end{array}$ & $0.30 * *$ \\
\hline
\end{tabular}

Regarding the component "object of evaluation", we observe that Cronbach's Alpha is 0.57 and that the four elements from the literature review are significant.The respective weight of the four explanatory variables is seen in the results of the regression model:

Table 4: Study of the model and the regression coefficients of the PP objects

\begin{tabular}{|c|c|c|c|c|c|}
\hline Variables & Beta coefficients & $\begin{array}{l}\text { Standard } \\
\text { deviation }\end{array}$ & Wald & Signif. & Exp(B) \\
\hline (constant) & -1.277 & 3.086 & 9.668 & .002 & .001 \\
\hline Performance of individuals & 0.156 & .010 & 2.282 & .140 & $2,344 \mathrm{E}-02$ \\
\hline Performance of higheradmin. & 1.286 & .451 & 8.149 & .004 & 3.634 \\
\hline $\begin{array}{c}\text { Performance of local authority } \\
\text { Performance of public policies and } \\
\text { of initiatives undertaken }\end{array}$ & 1.521 & .482 & 9.961 & .002 & 4.939 \\
\hline
\end{tabular}

Model significant at 1\%; R2 Nagelkerke ${ }^{4}: 0.73$; correct ranking: $95.1 \%$

\footnotetext{
${ }^{3}$ For example: Table 5 shows the 16 variables to ascertain whether the objectives are multiple or not. These variables are derived from the literature review and are subject to a test of significance ( $1 \%$ threshold) then the entire scale is checked by Cronbach's alpha to assess the relevance of variables relative to the measured object. Then the variable "multi-objective" is made by a binary score (score exceeding or not the average of the expected answers) to check via a logistic regression which are the most explanatory variables in the fact of being multi-objective or not.

${ }^{4}$ The regression model shows $73 \%$ of the variance explained; it is significant at the threshold of $1 \%$ (F: 44 , sig.0.00). This significance shows the existence of at least one explanatory variable exercising a significant influence on the dependant variable.
} 
This regression model shows that two variables have a statistically significant influence on the characteristic "object" of PP, namely local authority performance and higher administration performance. With these two variables, the regression model can correctly predict $95 \%$ of the rankings. Note that the variable "individual performance" is statistically significant at the threshold of $10 \%$, but its high correlation with variable 3 reduces the effectiveness of the model when it is taken into account. The correlation and the regression analysis performed on the objects of PP (tables 2 and 3 ) both validate the multidimensional character of the objects ( $\mathrm{H} 1$ validated).

\subsection{Analysis of the objectives of public performance}

To assess the objectives pursued in PP approaches, sixteen variables, derived from the literature, are put forward. The five dimensions previously identified are revealed by the principal component analysis conducted on the explanatory variables.

Table 5: Results of the correlation about the objectives pursued

\begin{tabular}{|c|c|}
\hline \multicolumn{2}{|l|}{ Multi-objectives } \\
\hline & $\alpha: 0.71$ \\
\hline appropriately allocate spending and resources to organizational objectives & $0.40 * *$ \\
\hline economically allocate resources to policies undertaken & $0.19 *$ \\
\hline ensure compliance of initiatives undertaken with regulations & $0.40 * *$ \\
\hline optimize revenue & $0.34 * *$ \\
\hline recruit, motivate and deploy the personnel & $0.60 * *$ \\
\hline respond to the personnel's aspirations to well-being & $0.43 * *$ \\
\hline control the volume of local public services on offer & $0.36 * *$ \\
\hline control the quality of local public services & $0.49 * *$ \\
\hline meet users' needs at the right levels of satisfaction & $0.41 * *$ \\
\hline meet citizens' needs at the right levels of satisfaction & $0.52 * *$ \\
\hline meet local actors' needs at the right levels of satisfaction & $0.40 * *$ \\
\hline communicatewith the stakeholders & $0.53 * *$ \\
\hline $\begin{array}{l}\text { learn from one's practices in order to improve the allocation of resources to } \\
\text { organizational objectives }\end{array}$ & $0.50 * *$ \\
\hline learn from one's practices in order to reorient the objectives of the organization & $0.64 * *$ \\
\hline adapt the structure of the organization to the strategy of the local authority & $0.52 * *$ \\
\hline develop common standards, rules, and values for projects and results & $0.38 * *$ \\
\hline
\end{tabular}

** $1 \%$

Regarding the objectives of PP, all items are significant at the threshold of $1 \%$.Studying the relative importance of the explanatory variables, we see that the regression coefficients of the model reveal three significant factors. The three significant variables of the regression model explain $68.5 \%$ of the variation of the dependant variable, ranking almost $96 \%$ of individuals correctly. These variables, which explain the objectives of PP (meet citizens' needs, learn from one's current and past practices in order to improve the allocation of resources to organizational objectives, and recruit and motivate the personnel), concern the internal and external environment of the local authority. These analyses 
thus enable one to capture a multidimensional conception of PP in its territorial, public service, organizational, human and financial components (Hood, 1995; Bouckaert and Pollitt, 2004; Moullin, 2002).

The regression model uses four main variables to explain the objectives of public performance. We are concerned with the measurement of the characteristics revealed by our theoretical study of the objectives pursued in PPM. These characteristics (meeting citizens' needs; learning from one's current and past practices in order to better align the allocation of resources with the objectives of the organization; adapting structure to strategy; motivating the personnel) concern the internal and external environments of the local authority. These analyses enable one to achieve a multidimensional conception of public performance, integrating its territorial, public service, organizational, human and financial components (Hood, 1995; Bouckaert\&Pollitt, 2004; Moullin, 2002).

Table 6: Study of the model and of the regression coefficient

\begin{tabular}{|c|c|c|c|c|c|}
\hline Variables & $\begin{array}{c}\text { Beta } \\
\text { coefficients }\end{array}$ & $\begin{array}{c}\text { Standard } \\
\text { deviation }\end{array}$ & Wald & Signif. & Exp(B) \\
\hline (constant) & -18.277 & 9.086 & 5.668 & .021 & .001 \\
\hline $\begin{array}{c}\text { recruit, motivate and deploy the personnel } \\
\text { meet citizens' needs at the right levels of } \\
\text { satisfaction }\end{array}$ & 2.638 & 1.158 & 2.001 & 0.098 & 5.144 \\
\hline $\begin{array}{c}\text { adapt the structure of the organization to } \\
\text { the strategy of the local authority }\end{array}$ & 3.958 & 2.145 & 1.584 & 0.109 & 3.425 \\
\hline $\begin{array}{c}\text { learn from one's practices in order to } \\
\text { improve the allocation of resources to } \\
\text { organizational objectives }\end{array}$ & 2.152 & 0.929 & 5,448 & 0.019 & 8.602 \\
\hline
\end{tabular}

R2 Nagelkerke: 0.685; ranking correct: $95.8 \%$

\subsection{Analysis of the measures of public performance}

To assess the useable measures of PP, thirteen variables were put forward.

Table 7: Results of correlation on the "measure" variables

\begin{tabular}{|c|c|}
\hline Multi measure & $\alpha: 0.76$ \\
\hline level of consumption of resources deployed & $0.30^{* *}$ \\
\hline level of revenue realization & $0.24^{*}$ \\
\hline volume of acts rejected by prefectural decision on grounds of legality & $0.20^{*}$ \\
\hline importance of assumption of legal responsibility by the local government authority & $0.26^{* *}$ \\
\hline degree of realization of initiatives undertaken (political, projects, etc.) & $0.46^{* *}$ \\
\hline intensity of impact and of effects of public policies & $0.43^{* *}$ \\
\hline estimated quality of local public services & $0.46^{* *}$ \\
\hline perceived quality of local public services & $0.53^{* *}$ \\
\hline degree of satisfaction of taxpayers & $0.39^{* *}$ \\
\hline
\end{tabular}




\begin{tabular}{|c|c|}
\hline degree of satisfaction of users & $0.41^{* *}$ \\
\hline degree of satisfaction of citizens & $0.45^{* *}$ \\
\hline level of quality of internal processes & $0.30^{* *}$ \\
\hline level of development of human qualities (commitment, motivation, potential, well-being) & $0.30^{* *}$ \\
\hline
\end{tabular}

$$
* * 1 \% ; * 5 \% \text {, }
$$

Three variables have a significant influence according to the regression model obtained.

Table 8: Study of the model and the regression coefficients of the PP measures

\begin{tabular}{|c|c|c|c|c|c|}
\hline Variables & $\begin{array}{l}\text { Beta } \\
\text { coef. }\end{array}$ & $\begin{array}{l}\text { Standard } \\
\text { deviation }\end{array}$ & Wald & Signif. & $\operatorname{Exp}(B)$ \\
\hline (constant) & -1.677 & 9.986 & 5.168 & .023 & .000 \\
\hline $\begin{array}{l}\text { degree of realization of initiatives undertaken } \\
\text { (political, projects, etc.) }\end{array}$ & 1.863 & .674 & 3.578 & .056 & 6.441 \\
\hline degree of satisfaction of citizens & 2.531 & 1.197 & 4.473 & .034 & 12.565 \\
\hline perceived quality of local public services & 1.763 & .435 & 3.088 & .113 & 3.435 \\
\hline $\begin{array}{c}\text { level of development of human qualities } \\
\text { (commitment, motivation, potential, well-being) }\end{array}$ & 2.151 & 1.233 & 3.045 & .081 & 8.573 \\
\hline
\end{tabular}

Dependant variable: multi-measures; R2 Nagelkerke: 0.87; Correct Ranking: 98.4\%

Four measures of PP are used in this regression model: citizens' degree of satisfaction, level of human capital, and degree of realization of initiatives undertaken. The presence of these variables is particularly interesting since these measures are qualitative and long-term and are often difficult to obtain. They are original, in that they contrast with the often short term measures of a budgetary and accounting nature that are traditionally used (Epstein and Manzoni, 1998). As respondents seem to be expressing the ideal measures they'd like to use to evaluate public performance, what we obtain is an ideal rather than a useable set of factors. In fact, in a comprehensive analysis, if we take account of local authorities' obligation to conduct a financial and accounting treatment of their resources, we can capture the multidimensional character of PP measures and thereby validate $\mathrm{H} 3$. We now turn to examine the "learning" characteristics of public performance.

\subsection{Analysis of the learning characteristics of public performance}

To assess public performance learning, we put forward nine variables that validate the two modes of learning distinguished theoretically.

Table 9: Results of correlation of the learning factors

\begin{tabular}{|c|c|}
\hline \multicolumn{1}{|c|}{ Multi learning } & $\alpha: 0.63$ \\
\hline $\begin{array}{c}\text { learn from one's current and passed practices in order to improve the allocation of } \\
\text { resources to organizational objectives }\end{array}$ & $0.50^{* *}$ \\
\hline $\begin{array}{c}\text { learn from one's current and passed practices in order to reorient the objectives of the } \\
\text { organization }\end{array}$ & $0.64^{* *}$ \\
\hline develop common standards, rules, and values for projects and results & $0.52^{* *}$ \\
\hline $\begin{array}{c}\text { adapt the human, financial and technical resources to the objectives of the local authority } \\
0.34^{* *}\end{array}$ \\
\hline
\end{tabular}




\begin{tabular}{|c|c|}
\hline adapt the administrative and political structure to the strategy of the local authority & $0.48^{* *}$ \\
\hline motivate the personnel (reward according to individual and collective performance) & $0.56^{* *}$ \\
\hline take a more proactive role or reorient public policies to be implemented & $0.48^{* *}$ \\
\hline $\begin{array}{c}\text { influence the allocation of resources between national and local government authorities } \\
\text { Improve the quality of information communicated to local actors (users, citizens, } \\
\text { taxpayers, banks, companies, etc.) }\end{array}$ & $0.42^{* *}$ \\
\hline \begin{tabular}{c} 
taxp \\
\hline
\end{tabular}
\end{tabular}

$* * 1 \%$.

For the nine variables of the 'learning' dimension of PP, Cronbach's alpha (0.63) is relatively weak, but the items are significant at $1 \%$.For the variables at work in the 'learning' characteristic, the logistic regression model reveals three significant variables out of the nine.

Table 10: Results of the regression of the PP learning variables

\begin{tabular}{|c|c|c|c|c|c|}
\hline Variables & Beta coeff. & $\begin{array}{c}\text { Standard } \\
\text { deviation }\end{array}$ & Wald & Signif. & Exp(B) \\
\hline (constant) & $-7.297 \mathrm{E} 01$ & 2.686 & 7.968 & .005 & .001 \\
\hline $\begin{array}{c}\text { adapt the human, financial and technical } \\
\text { resources to the objectives of the local authority }\end{array}$ & 2.156 & 0.621 & 2.85 & 0.09 & 1.869 \\
\hline $\begin{array}{c}\text { motivate the personnel (reward according to } \\
\text { individual and collective performance) }\end{array}$ & 1.433 & .426 & 10.248 & 0.010 & 3.073 \\
\hline $\begin{array}{c}\text { improve the quality of information } \\
\text { communicated to local actors (users, citizens, } \\
\text { taxpayers, banks, companies, etc.) }\end{array}$ & 1.193 & .432 & .371 & 0.001 & 3.798 \\
\hline
\end{tabular}

Model significant at 1\%; R2 Nagelkerke: 0.728 ; correct ranking: $96.4 \%$

The regression model, with three significant variables, explains $73 \%$ of the variation and ranks $96 \%$ of the individuals. The main types of learning pursued bear on the internal and external finalities of public performance, namely motivating the personnel (the human dimension) and improving the quality of information communicated to partners (the territorial dimension). In sum, thanks to the regression conducted on the PP learning variables, we can confirm the multidimensional character of the learning variables and validate $\mathrm{H} 4$.

We now turn to examine the targets concerned by the information provided by the system of public performance.

\subsection{Analysis of the targets of public performance}

To assess the public performance targets, nine variables were put forward to respondents. We conducted a PCA on all the explanatory variables in order to check whether the factorial axes enable the identification of the dimensions of PP.

Table 11: Results of correlation of the "target" variables

\begin{tabular}{|c|c|}
\hline Multi target & $\alpha: 0.79$ \\
\hline the citizen & $.19^{*}$ \\
\hline the taxpayer & $.43^{* *}$ \\
\hline the user & $.38^{* *}$ \\
\hline
\end{tabular}




\begin{tabular}{|c|c|}
\hline the banker & $.48^{* *}$ \\
\hline the national government & $.43^{* *}$ \\
\hline the local governmentauthority & $.49^{* *}$ \\
\hline the agents & $.50^{* *}$ \\
\hline the establishedcompanies & $.61^{* *}$ \\
\hline the prospective companies & $.60^{* *}$ \\
\hline
\end{tabular}

** $1 \% ; * 5 \%$.

For the nine variables of the 'target' dimension of PP, Cronbach's alpha (0.79) and the significance of the items are good, in line with the conclusions of the literature review.

To complement this exploratory approach, we sought to discover the significant variables in the regression model. Five factors emerged:

Table 12: Study of the model and the regression coefficients of the PP targets

\begin{tabular}{|c|c|c|c|c|c|}
\hline Variables & Beta coefficients & $\begin{array}{c}\text { Standard } \\
\text { deviation }\end{array}$ & Wald & Signif. & Exp(B) \\
\hline (constant) & -21.877 & 8.986 & 10.168 & .001 & .000 \\
\hline the taxpayer & 0.763 & .435 & 3.088 & 0.079 & 2.147 \\
\hline the user & 1.858 & .757 & 6.200 & 0.013 & 6.578 \\
\hline the local governmentauthority & 2.430 & .810 & 9.005 & 0.003 & 11.310 \\
\hline the agents & 1.472 & .616 & 5.906 & 0.015 & 4.351 \\
\hline the prospective companies & 3.529 & 1.170 & 9.058 & 0.003 & 34.094 \\
\hline
\end{tabular}

Model significant at 1\%; R2 Nagelkerke: 0.891; correct ranking: $97 \%$

The significant variables in this regression model concern actors as much internal as external to the local authority. Taxpayers, prospective companies and users represent targets external to the local authority, while the higher administration and the agents illustrate the communication of information to internal actors. In finding the multiple character of the dimension "target" in the explanation of $\mathrm{PP}$, we validate $\mathrm{H} 5$.

Finally, we conclude our study of the characteristics of public performance with an analysis of its underlying rationales.

\subsection{Analysis of the rationales of public performance}

To assess the rationales of PP, eight variables were put forward to respondents. The exploratory analysis by PCA enabled the identification of three dimensions within the rationales of PP.

Table 13: Results of the correlation of the "rationales pursued" variables

\begin{tabular}{|l|c|}
\hline & \\
\hline Multi rationale & $\alpha: .80$ \\
\hline Regulation of economicactivity & $.45^{* *}$ \\
\hline General interest & $.39^{* *}$ \\
\hline
\end{tabular}




\begin{tabular}{|l|l|}
\hline Social justice & $.50^{* *}$ \\
\hline Compliance/legality & $.44^{* *}$ \\
\hline Return on investment & $.25^{* *}$ \\
\hline Productivity & $.41^{* *}$ \\
\hline Effectiveness & $.29^{* *}$ \\
\hline Efficiency & $.53^{* *}$ \\
\hline
\end{tabular}

Cronbach's alpha (0.8) and the significance of the items are good, in line with the conclusions of the literature review.

Complementary to this analysis, the regression model identifies the significant explanatory variables (table 13). With three explanatory factors used in the model, the equation enables the correct ranking of $97 \%$ of the individuals for the explained variable "underlying rationales of PP". The presence of variables derived from both the private sector (efficiency, productivity) and the public sector (legality and compliance) is explained by the multiple constraints (financial, organizationaland territorial) to which local authorities are subject.

Table 14: Study of the model and regression coefficients of the rationales of PP

\begin{tabular}{|c|c|c|c|c|c|}
\hline Variables & Beta coefficients & $\begin{array}{c}\text { Standard } \\
\text { deviation }\end{array}$ & Wald & Signif. & Exp(B) \\
\hline (constant) & -2.877 & 1.986 & 1.468 & .035 & .000 \\
\hline Compliance/legality & 2.819 & 1.320 & 4.565 & .033 & 16.705 \\
\hline Productivity & 1.720 & .911 & 3.610 & .058 & 5.593 \\
\hline Efficiency & 3.811 & 1.905 & 4.061 & .041 & 45.070 \\
\hline
\end{tabular}

Model significant at 1\%; R2 Nagelkerke: 0.871 ; correct ranking: $97 \%$

These statistical analyses enable the validation, in the local context, of our hypothesis concerning the multiple and contingent character of public performance and they reveal the dimensions of public performance - territorial, public service, organizational, human, financial.

We have confirmed, via an empirical study conducted in the local public sector, the multidimensional character of objects, objectives, measures, learning, rationales and targets of public performance. Indeed, our contribution to the literature emphasizes the necessity for public organizations to pursue multiple objectives in terms of resources and public service realizations and their environmental effects. Thus, we can make some recommendations.

About the dimension in relation with the means mobilized, the public organization must master its deployment of:

- human resources: optimize the effectiveness of its services (CAF and PSS models);

- financial resources: ensure compliance and economy in its spending, respecting its sources of finance, namely the State, taxpayers and banks (Hood's model);

- organizational resources (foster cognitive, cultural and structural learning (Bouckaert and Pollitt's model; CAF).

At the level of "public service dimension", the organization must produce a public service offer of sufficient quantity and quality, satisfying the user (Hood's model; the PSS model; the CAF). Finally, at the level of "territorial dimension", the public organization must, by its public service offer, make a 
durable impact on its territory by meeting the socio-economic needs of citizens and companies and communicating openly and reliably about initiatives undertaken and resources deployed (Bouckaert and Pollitt's model).

Via a synoptic vision, then, we can define public performance as the capacity of an organization to control its human, financial and organizational resources, in order to produce an appropriate public service offer (in terms of quality and quantity) that meets the needs of its stakeholders and generates positive effects on its territory.

\subsection{Summary of the results and managerial implications}

Ultimately, our study empirically validates the multidimensionality of the concept of public performance, usually affirmed in the literature without being demonstrated, and this in itself constitutes one of the contributions of our research. Although this is confirmed, it would seem that the modalities constituent of each of the dimensions vary by country, and even by public organization. Thus the French local authorities show a largely internal and administrative conception of public performance, favoring indicators of activity and input and focusing mainly on the dynamics of efficiency. The rationalization of budgetary decisions, the monitoring of activities, and a communication oriented towards internal public actors are all elements characteristic of the French model (Carassus andGardey, 2009). Conversely, a number of studies (Folzand al., 2009; Fryer and al., 2009; Talbot, 1999) have shown that the UK and the USA have a much broader and externallyoriented conception of public performance, as much in its measurement and use as in its communication. Here, the accent is placed on the evaluation of the social impact of public policies and programmes (Ammons andRivenbark, 2008), on a communication oriented towards users and the local population, and on a sustained involvement of external stakeholders. These national differences in performance management, already observed by Pollit (2005), could be explained by the countries' or public organizations' stage of development. The initial stages (the French case) are characterized by a limited approach to public performance, restricted to problems of efficiency and monitoring of activities and favoring internal learning. This geographic or cultural variability of the notion of public performance, already observed by Siegel andSummermatter (2009), promises to be a fruitful area for future research.

Our empirical findings concur on another point with those of Siegel andSummermatter (2009), namely the multidimensional nature of the concept of public performance, characterized by complexity and ambiguity. This reality complicates the definition, measurement and use of the concept of public performance, as much by public practitioners and managers as by academic researchers.

\section{Conclusion}

Our analysis of the literature on the models of public performance management revealed the partial character of these models, an inadequacy due to an insufficient taking into account of the specificities of public performance. Indeed, the models of Hood (1995), Bouckaert and Pollitt (2004), Talbot (1999), adopting an economic approach, and those of Moullin (2002) and of the CAF (2006), which adopt a partnership approach, do not integrate, individually, all the dimensions of public performance. We therefore set out, in the framework of this study, to go beyond these limits, by testing a model that takes account of all the identified characteristics of public performance.

In order to test the empirical realism of this model, we conducted, in the context of a national survey, statistical analyses that validated the multidimensional character of the objects, objectives, measures, learning, targets and rationales of public performance, as well as the five dimensions that we identified. 
Our study model of public performance is validated in the French local-government context. Its confirmation substantiates our characterization and definition of public performance, enriching the prior literature by going beyond a partial vision of organizational performance to integrate the politico-environmental specificities of the public sector via the "public service" and "territorial" dimensions. From an operational point of view, these conceptual and theoretical contributions can also serve to guide public organizations in the politico-administrative management of their resources and activities.

One of the extensions of this research work could be to study and test a more fundamental or higher-order concept of public performance, as suggested by Verbeeten (2008) andBouckaertandHalligan (2008), namely the concept of legitimacy or confidence. According to Verbeeten (2008), legitimacy can be considered both as a dimension of public performance and as a finality of performance management. The process by which public organizations set goals and measure progress towards their achievement is relevant here. For their part, Bouckaert andHalligan (2008) insist on the necessity of considering citizens' confidence in the political system as a component of public performance. Confidence is thus seen to be positioned at the end of a public value chain and as part of a causal relationship such as Inputs-Activities-Outputs-Outcomes-Trust.

Nevertheless, if this study attests to the multidimensional character of public performance in the particular context of local government, it should be followed up by studies testing the validity of the model in organizations that produce an impact on the territorial level (public and semi-public organizations and those belonging to the social economy). It is also relevant to investigate the degree of integration in the private sector of the politico-administrative dimensions of public performance, legitimated by the socio-economic impact of companies' productive activity. Moreover, as this study targeted large public organizations (local governments of towns of at least 50,000 inhabitants), testing its adaptability to small organizations would seem to be necessary. Finally, we used declarative data, meaning that it is the respondents' perceptions of public performance that inform their responses, but an on-site analysis could reveal practices different from those announced.

In order to analyze the universal, as opposed to contingent, character of our definition of public performance and to understand how these characteristics differ between public and private organizations, we suggest follow-up research be conducted to test our model, first with other public structures such as university and hospital administrations, and then with SMEs and big companies. Indeed, our model, derived from public management theory, would seem to concern the functioning of all large organizations that have a socio-economic impact across a given territory. 


\section{Bibliography}

Aidemark L-G. (2001), "The Meaning of Balanced Scorecards in the Health Care Organization", Financial Accountability \& Management, Vol. 17, n¹, p. 23-40.

Ammons D. N., Rivenbark W. C. (2008), "Factors Influencing the Use of performance Data to Improve Municipal Services: Evidence from the North Carolina Benchmarking project ", .Public Administration Review, Vol. 68, n², p. 304-318.

Amstrong J. (1997), "Stewardship and public service ", Commission de la fonctionpublique du Canada.

Argyris C., Schon D. (1978), " Organizational learning », Reading Mass: Adisson-Wesley.

Ax C., Bjornenak T. (2000), " The Bundling and Diffusion of Management Accounting Innovations. The Case of the Balanced Scorecard in Scandinavia ", 23rd Annual Congress of the European Accounting Association, Munich.

Bouckaert G., Pollitt C. (2004), Evaluating public management reforms: a comparative analysis, Oxford University Press.

Bouckaert G., Halligan J. (2008), " Managing performance, International comparisons ", Routledge, London.

Boyne G.A. (2002), "Concepts and Indicators of Local Authority Performance: An Evaluation of the Statutory Frameworks in England and Wales ", Public Money and Management, Vol. 22, n², p. 1724.

Carassus D., Gardey D. (2009), " Une analyse de la gestion de la performance par les collectivités locales françaises : un modèle administratif ou politique? ", Revue Française de Finances Publiques, $n^{\circ} 107$, p. 101-120.

Chapet J.-M. (2007), « Le système de gestion des collectivités territoriales : entre performance et délibération », Politique et Management Publics, vol. 25, nº. 4, p. 1-21

Chow C.-W., Ganulin D., Haddad K., Williamson J.(1998), « The Balanced Scorecard: A Potent Tool for Energizing and Focusing Healthcare Organization Management ", Journal of Health Care Management, Vol. 43, n³, p. 263-80.

De Brujin, H. (2002), " Performance Measurement in the Public Sector. Strategies to cope with the risks of performance measurement ", International Journal of Public Sector Management, Vol. $15 \mathrm{n}^{\circ}$ 6-7, p. 578-594.

Lorino P. (1997), “Contrôle de gestion et pilotage”, Paris (France), Nathan.

European Institute of Public Administration (EIPA) (2006), The Common Assessment Framework (CAF). Improving an organisation through self-assessment, CAF Resource Centre.

Epstein M., Manzoni J-F. (1998), "Implementing corporate strategy : from tableaux de bord to balanced scorecards", European Management Journal, Vol. 16, n², p. 190-203.

Folz D. H., Abdelrazek R., CHUNG Y. (2009), "The Adoption, Use and impactsof performance Measures in medium-SizeCities: Progress TowardPerfromance Management", Public Performance and Management Review, Vol. 33, n¹, p. 63-87.

Fryer K., Anthony J., Ogden S. (2009), "Performance Management in the Public Sector", International Journal of Public Sector Management, Vol. 22, n6, p. 478-498 
Guenoun M. (2009), « Le management de la performance publique locale : Etude de l'utilisation des outils de gestion dans deux organisations intercommunales", PhD in management science Université Paul Cézanne.

Halachmi A. Bouckaert G. (1996), Organizational Performance and Measurement in the Public Sector: Toward Service, Effort and Accomplishment Reporting, Greenwood Publishing Group.

Hirst P. (2000), "Democracy and Governance", in J. Pierre (ed.), DebatingGovernance: Authority, Steering and Democracy, Oxford: OxfordUniversityPress

Hood C. (1991), "A Public Management for All Seasons ", Public Administration Review, Vol.69, n¹, p. 3-19.

Hood C. (1995), "Contemporary Public Management: A New Global Paradigm? », Public Policy and Administration, Vol. 10, n², p. 104-117.

Jansen E.P. (2008), New public management: perspectives on performance and the use of performance information. Financial Accountability \& Management, vol 24, n² 2, p.169-191.

Kaplan R.S., Norton D.P. (1996), "The Balanced Scorecard : Translating Strategy into Action ", Harvard Business School Press, Boston.

Mc Adam R., Hazlett S-A., Casey C., (2005), "Performance management in the UK Public Sector: addressing Multiple Stakeholder Complexity", International Journal of Public Sector Management, Vol. $18, n^{\circ} 3$, p. 256-273.

Mc Kendrick J., Hastings M.(2002), " The Development of a Performance Framework for Professions Allied to Medicine in Rehabilitation ", Annual Congress of the British Accounting Association, St. Helier.

Mednick R., (1991), "Reinventing the audit », Journal of Accountancy, August, p.71-78.

Moullin M. (2002), "Delivering Excellence in Health and Social Care », Open University Press, Buckingham.

Moullin M. (2006), The Design of an Alternative Balanced Scorecard Framework for Public and Voluntary Organizations", Perspectives on performance, vol. 5, $n^{\circ} 1$, Performance Measurement Association.

Moynihan, D.-P. (2005), "Why and How do State Governments Adopt and Implement " Managing for Results " Reforms ? ", Journal of Public Administration Research and Theory, Vol. 15, n², p. 219243.

Neely A., Adams C., Kennerly K. (2002), "The Performance Prism », Financial Times, Prentice-Hall, London.

Newcommer K. E. (2007), "MeasuringGovernment performance", International Journal of Public Administration, Vol. 30, n³, p. 307-329.

Olsen, J. P. (2003), "Citizens, Public Administration and the Search for Theoretical Foundations ", Working Papers, ARENA 20/03.

Pollitt C. (2006), "Performance Management in Practise: a comparative Studyof Executive agencies", Journal of Public AdministrationResearch and Theory, Vol.16, n¹, p. 25-44.

Smith P. (1996), "A Framework for Analysing the Measurement of Outcome ", in P. Smith (Ed.), Measuring Outcome in the Public Sector, London, Taylor \& Francis Ltd.

Siegel J.P, Summermatter L. (2009), "Defining Performance in Public Management: Variations over Time and Space", IRSPM XXIII, Copenhagen, 6-8 april. 
Talbot C. (1999), "Public Performance - Toward a New Model ? ", Public Policy and Administration, Vol. 14, n³, p.15-34.

Verbeeten F. (2008). Performance management practice in public sectororganizations Impact on performance. Accounting, Auditing \&Accountability Journal, Vol. 21, n³, p. 427-454.

Vigoda E. (2002). "From responsiveness to collaboration: Governance, citizens, and the next generation of public administration." Public Administration Review, vol 62, n5, p. 527-540. 